\title{
THE MEANING OF INTERACTION BETWEEN NURSING PROFESSIONALS AND NEWBORNS/ FAMILIES IN A HOSPITAL SETTING
}

\author{
Eliana Moreira Pinheiro \\ Maria Júlia Paes da Silva² \\ Margareth Angelo ${ }^{2}$ \\ Circéa Amália Ribeiro ${ }^{1}$
}

Pinheiro EM, Silva MJP, Ângelo M, Ribeiro CA. The meaning of interaction between nursing professionals and newborns/families in a hospital setting. Rev Latino-am Enfermagem 2008 novembro-dezembro; 16(6):1012-8.

This study aimed to understand the meaning of the nursing team's communication with newborns and families during care delivered in a neonatal unit and also to develop a theoretical model. Symbolic Interactionism and Hargie's model were used as theoretical and Grounded theory as the methodological reference framework. The study was carried out at the nursery of a hospital in São Paulo, SP, Brazil. The study sample was composed of three nurses and four nursing auxiliaries. The theoretical model Being mediated by the strength of motivation was based on findings and revealed the role the nursing professionals' motivation played during interactions with newborns and families. The conclusion is that more humanized interactions with newborns and families result from the nursing professionals' motivation.

DESCRIPTORS: communication; newborn; motivation; nursing

\section{EL SIGNIFICADO DE LA INTERACCIÓN DE LAS PROFESIONALES DE ENFERMERÍA CON EL RECIÉN NACIDO/FAMILIA DURANTE LA HOSPITALIZACIÓN}

Este estudio tuvo por objetivos comprender el significado de la comunicación del equipo de enfermería con el recién nacido/familia en la asistencia prestada en una unidad neonatal, y desarrollar un modelo teórico. Se utilizó el Interaccionismo Simbólico y el modelo de Hargie como marcos teóricos y la Teoría Fundamentada en los Datos como referencia metodológica. El estudio fue conducido en la sala cuna de un hospital del municipio de San Pablo. La muestra fue constituida por tres enfermeras y cuatro auxiliares de enfermería. Los resultados posibilitaron obtener el modelo teórico siendo intermediada por la fuerza de la motivación, que reveló la actuación de la motivación de las profesionales de enfermería en la interacción con el recién nacido y la familia. También, se concluyó que las interacciones con el recién nacido y la familia como esencia más humanizada son provenientes de la motivación que las profesionales de enfermería presentan.

DESCRIPTORES: comunicación; recién nacido; motivación; enfermería

\section{O SIGNIFICADO DA INTERAÇÃO DAS PROFISSIONAIS DE ENFERMAGEM COM O RECÉM- NASCIDO/FAMÍLIA DURANTE A HOSPITALIZAÇÃO}

Este estudo teve por objetivos compreender o significado da comunicação da equipe de enfermagem com o recém-nascido/família na assistência prestada em unidade neonatal, e desenvolver um modelo teórico. Utilizouse o Interacionismo Simbólico e o modelo de Hargie como referenciais teóricos e a Teoria Fundamentada nos Dados como referencial metodológico. O estudo foi conduzido em berçário de um hospital do município de São Paulo. A amostra foi constituída por três enfermeiras e quatro auxiliares de enfermagem. Os resultados possibilitaram obter o modelo teórico sendo mediada pela força da motivação, que revelou a atuação da motivação das profissionais de enfermagem na interação com o recém-nascido e família. Concluiu-se, também, que as interações com o recém-nascido e a família como essência mais humanizada são decorrentes da motivação que as profissionais de enfermagem apresentam.

DESCRITORES: comunicação; recém-nascido; motivação; enfermagem

\footnotetext{
${ }^{1}$ Adjunct Professor, Federal University of São Paulo, Brazil, e-mail: elianapinheiro@hotmail.com, circea@denf.epm.br; ${ }^{2}$ Full Professor, University of São Paulo
} School of Nursing, Brazil, e-mail: juliaps@usp.br, angelm@usp.br. 


\section{INTRODUCTION}

Neonatal nursing care is an interactional process of three channels: it involves interactions between the professional/newborn and professional/ newborn and family ${ }^{(1-2)}$.

Considering that newborns do not verbalize, their non-verbal signs need to be decoded by nursing professionals, so that they can identify and interpret signs babies display, because of pain or other alterations in their health, and proper care can be delivered and shared with family members. Nursing professionals can also favor interaction between baby and family while providing care to the newborn. This way, understanding of the child's behaviors and knowledge of their peculiarities can be transmitted to the family members, aiming to help them to interact with the baby, promoting the development of their new role and bonding.

Research has showed that an infant's hospitalization process is a stressing experience for parents and that it is very difficult for them to be apart from their child $^{(3-4)}$.

Interpersonal communication is a key element for nursing professionals in supporting the family and making it a partner in the care delivered to the baby. Depending on the way these interactions are established, it is possible to help the family understand the reality involving this new moment in the family cycle.

A study verified that nurses, characterized as facilitators of mothers' abilities, established interactions at a personal and friendly level. Yet nurses who conducted superficial and short communication with mothers limited their participation in the dialog and inhibited mothers' verbalization of their needs and concerns ${ }^{(5)}$.

Even the best nurses who work in neonatal units can have difficulty showing the most humane side of nursing, which is the sharing of care delivered to the newborn with the family, offering support and putting the needs of family members above their own $^{(6)}$

It has been observed in practice that the care delivered by nursing professionals to newborns is based on rigid routines and that the family is not always included in the care planning. In the scenario of interpersonal relations of nursing professionals, we perceive that the communication of nurses and nursing auxiliaries is used as a little known skill, based only on the sociocultural context they belong to as individuals.

Acknowledging the importance of nursing professionals' interaction for the care delivered to the newborn and family during the hospitalization process and also understanding that interpersonal communication is a little developed skill in our field, the following questions were raised: What is the experience of nurses and nursing auxiliaries in the interaction with newborns and family during the hospitalization process? Which communication elements are used by nursing professionals to meet the needs of babies and families and also to support affective bonding between them?

Based on these questions, this study aimed to understand the meaning of nursing team communication in the interaction with the newborn/ family during care delivery at a neonatal unit and develop a representative theoretical model of this experience.

\section{METHOD}

The theoretical reference frameworks for this study were Symbolic Interactionism $(\mathrm{SI})^{(7)}$, which presents a perspective of analysis of human experiences that focus on the nature of a person's interaction with the self and others and Hargie's ${ }^{(8)}$ model of interpersonal communication. The components of this model are: objectives people aim to achieve, motivation to achieve their objective, affective and cognitive processes that influence information processing, available feedback and people's perception in interactions, personal and contextual factors of communication and people's social responses during interactions. SI precepts and concepts permitted grasping the experience's intersubjective aspects and understanding the meaning attributed by nursing professionals to the communication between newborn and family.

The methodological reference adopted to guide data collection and analysis was Grounded theory. It aims to describe concepts that emerge from data and interpret the relation between these concepts, allowing for the construction of theoretical models ${ }^{(9)}$. Before collecting data, permission from the Research Ethics Committee was obtained and ethical criteria 
recommended in Resolution 196/96 for studies with human beings were complied with.

Data were collected at the nursery of a public hospital with 32 beds in São Paulo, SP, Brazil. Due to the population's demand, its capacity is oftentimes exceeded. Parents can stay at the unit from 7AM to 7PM. The nursing team is composed of six nurses and 26 nursing auxiliaries.

Three nurses and four nursing auxiliaries from three different shifts participated in the study. Two nurses were specialists, one in hospital administration and the other in public health. The nurses had worked at the nursery for more than seven years and the nursing auxiliaries for more than two years.

This number of participants was determined by the theoretical sampling process. While analysis was carried out and considerations were generated, new data were searched, which permitted the development and consolidation of categories. Thus, three sample groups were composed. The first comprised seven professionals and allowed the development of the initial categories that directed the collection of new data and formation of new groups to answer some questions that emerged in the initial data analysis. The objective with the second group was to consolidate the initial categories. This group was composed of three professionals; the third group, composed of two professionals, allowed for the validation of the proposed theoretical model.

Data collection was carried out between October 2001 and November 2002 by one of the researchers, using the following strategies: participant observation, - video recording through cameras fixed on the unit walls. These procedures occurred simultaneously and aimed to apprehend how interactions between professionals, child and family occurred during the baby's bath, diaper change, feeding and during visiting hours of other family members ${ }^{(10)}$, and - semi-structured interviews with professionals. These interviews were recorded, fully transcribed and guided by the following question: What does communication with the newborn and family mean to you?

Data were simultaneously collected and analyzed according to the Grounded theory, through the following stages: open codification, categorization, theoretical codification, identification and understanding of central category and proposition of theoretical model ${ }^{(11)}$.

\section{RESULTS}

Data analysis allowed for the construction of the theoretical model being mediated by the strength of motivation (Figure 1 ), which represents the meaning of nurses' and nursing auxiliaries' communication with the newborn and family at the hospital.

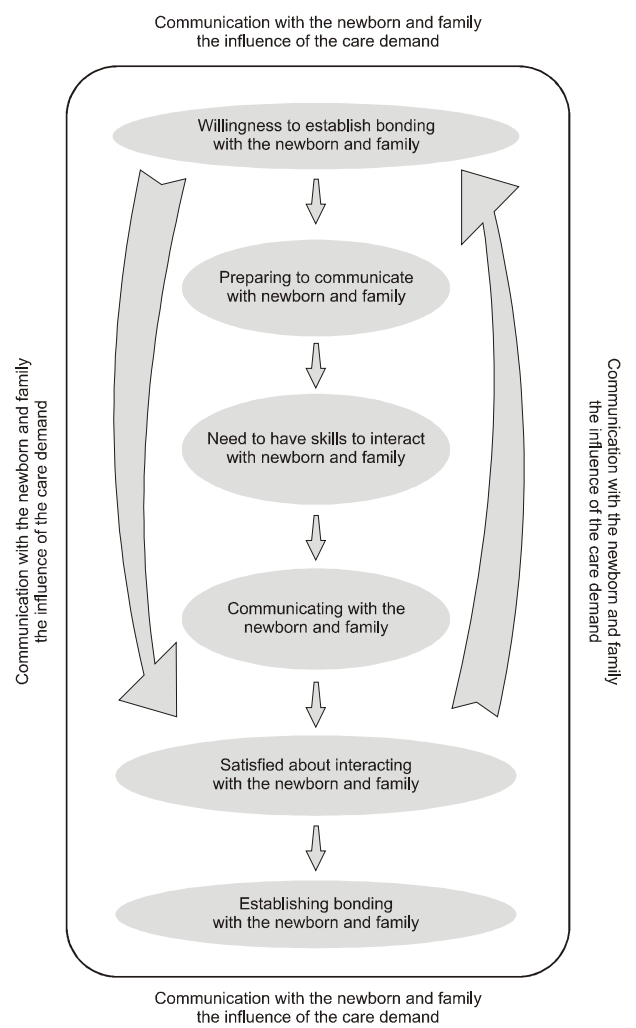

Figure 1 - Theoretical model: being mediated by the strength of motivation

The understanding of this experience was conceptualized and described in categories structured around the following elements: motivational, mobilizing, facilitating, defining and contextual. The central category wanting to establish bonding with the newborn and family is also considered one of the motivational elements.

The motivational elements reflect the influence of the professionals' motivation on the establishment of communication between the nursing team, the newborn and family. Motivation refers to the strength that makes professionals show specific actions in interactions with the child and family in the daily care routine.

Professionals feel motivated to communicate with newborns because they like to take care of them and because they acknowledge their physical and 
emotional dependency. Their motivation to communicate with family stems from the newborn. Babies make nurses and auxiliaries establish bonding with the infants and their families at the beginning of interactions - wanting to establish bonding with the newborn and family.

I like my work! It's not for the money, it's love in the first place...you see, the baby needs it. The child doesn't need only his mother in this phase, but everybody, needs care, affection (interview with nursing auxiliary - EA)

In order to establish bonding, professionals use means to interact with the baby and parents. This way, they transmit love to children during interactions and attend to families' needs; they understand that they have this responsibility because the newborn is under their care.

The responses nurses obtained to their cognitive and emotional processes during interactions experienced with newborns and families satisfied their own needs that emerged from the motivation satisfied about interacting with the newborn and family. Thus, they satisfy their social needs, self-esteem and selffulfillment by the way they delivered care to the baby and family during the interactions established while the baby is hospitalized.

I got satisfied for helping the mom breastfeed her child because she got happy to see the baby latched on and sucking the whole time (interview with nurse - EE).

In the communication process, the professionals perceive their own information regarding satisfaction of their needs, which emerged from interactions with the newborn and family. Thus, they observe and consider that they established bonding because of the affection they feel for the baby and friendship they made with the family - establishing bonding with the newborn and family.

Based on their motivation to establish bonding with the newborn and family, the professionals begin to interact. The mobilizing elements of the experience represent the categories that describe action that characterize the beginning of communication between professionals, newborns and families. These elements are presented around a goal established by professionals to interact with the baby, around their perceptions and considerations that result from decoding the child's reactions and family's actions and reactions.

Communicating with the newborn and family describes the professionals' movement towards the family and newborn. When they begin interaction through care, they establish a goal. Moved by their motivation, nurses and auxiliaries perform actions aiming to play the role of the baby's mother. When professionals define this goal, they establish strategies to get close to the baby because they know the child does not have the family around and have limitations to express him(er)self. When they interact with the child in this situation, they put themselves in the mother's place and care for the baby, giving him(er) love and affection.

You have to show lots of love when you're bathing the child, when you're changing diapers, if you have time, play with her, because the mother is not there all the time. So, I pretend I'm the mom, the grandma, everything! We play the mother's role in daily routine...(EA).

When professionals play the mother's role, they communicate with the child, interpreting her in the various interactions, and attribute meanings to the child's reactions; thus, they form impressions about the child. Interpreting the baby is a result of a set of perceptions professionals acquired from their own maternal and professional experiences.

Professionals also notice the newborn's capacity of perception by his(er) body language. They perceive babies are able to distinguish who is taking them on the lap with love and affection and who is interacting with no affection.

He knows when it's me who is taking care. I think he says, this is my grandma, this other one is my aunt, this one who just arrived is my mom. I guess he must know, because he gets all cheerful you know, all mellowed, making little noises (EA).

Motivated by the newborn, the nursing team prepares to interact with the family, to respond to mothers' attitudes at the first contact or when they arrive at the unit to visit the baby. When they perceive mothers are distant at first contact or when they observe mothers do not greet them when they enter the unit, the professionals approach the mothers, greet them and ask how they are, what their own and their children's names are. While professionals interact with the family, they identify what the family is like, attribute meanings to their actions and reactions and form their impressions regarding the parents.

The mothers, no matter how distant they are at first contact, I greet them. Hi mom? How are you? What's your name? It is important you know! What's your child's name? It's not Jane Doe's newborn? (EE).

Professionals perceive that the relationship between nurses, auxiliaries and families affect 
families' emotional state, feelings, sense of security and also acceptance of the care delivered to the baby.

Through the established goal of playing the mother's role, professionals use some strategies to ease interaction with the newborn and family. Thus, the facilitating elements of experience characterize the use of some of the professionals' personal skills to interact with the newborn and family. These abilities are strategies employed by the nursing team to ease communication with the baby during interactions, which consequently help them to communicate with the family.

To communicate with the baby, while playing the mother's role, the professionals consider that they use internal resources - have to have abilities to interact with the newborn and family. The use of professionals' skills, represented by perception, sensitivity and intuition, represents some of the strategies that help them to understand information transmitted by the child during interactions. By the use of internal resources like cognition and emotion, they transform and elaborate this information to generate their responses, moving towards the goals they established to interact with the baby. Consequently, this favors communication with the family, because the professionals prepare themselves to approximate mother and child, so as to favor the child's health recovery.

I told the mom her son was feeling abandoned because she wouldn't come to see him. Then, I told her to explain to the baby she was working and that she would come to visit more frequently. The mother is doing that and the child is getting better. The important thing for the mother is to communicate what I feel so she can work with her child, 'cause babies are very perceptive (EA).

Persisting in their motivation to establish bonding with the newborn and family, the professionals define and explain their actions. The defining elements of experience involve the categories that represent interpretations professionals experience with the newborn and family during nursing care communicating with the newborn and family. These elements are represented by some of the professionals' verbal and non-verbal behaviors, which are showed during interactions with babies and family, and through the target they defined for interaction with the family.

The display of these behaviors transcends the use of techniques that aim to meet physical needs and the baby's health recovery. Actions like calming the baby down, talking to him(er), explaining the care being delivered and praise, represent the way professionals communicate with the child in a more humanized way.

Nursing auxiliary takes the newborn on her lap from the changing table, kindly touches his chin and says to the child: you like to be caressed, don't you little one! (video recording-V).

Professionals need to give attention to the family members because the child is under their responsibility, so they establish the goal of meeting the family's needs. This goal is determined by their motivation to establish bonding with the baby and family. This goal makes them help the family to take care of the child, to understand and experience the newborn's hospitalization process. Aiming to achieve this goal, they establish strategies to interact with parents regarding several aspects that involve the child's hospitalization process, trying to keep them closer.

In this perspective, they communicate with the mothers, displaying verbal and non-verbal behaviors, giving them explanations, praising them, holding them to attend emotional needs, showing affection and communicating with them in different ways, as they perceive them and establish their impressions.

Nursing auxiliary enters the unit, touches the mother and says: you're looking good today! Lipstick on, had the hair done, right! (Observation note -ON).

Although motivation is an element that moves professionals to interact with the newborn and family, at some moments, it is inhibited by care demands. The contextual elements of the experience represent difficulties and influence of certain factors on the communication between professionals, newborn and family. When they prepare themselves to perform their tasks with a view to interacting with the newborn and family, professionals are influenced by some factors, including the child's several routine care procedures existent in all shifts, the work overload and noises present in at neonatal unit.

When professionals process their own information, based on the interactions with the newborn and family, and transform and elaborate it through their cognitive and emotional processes, they observe that their motivations are inhibited communication with the newborn and family is influenced by the care demand. In this circumstance, they no longer relate with the newborn, with whom they had established bonding, but interact with him only to attend his physical needs. 
It seems to me that, in the morning, professionals interact with the baby, deliver care aiming to use techniques. I perceived that, during the afternoon and night shifts, these interactions with the child seem to be more affectionate and attentive (ON and $\mathrm{V}$ ).

Difficulties in talking to the parents about the baby, no longer greeting them and giving no attention to the child, are some of the ways professionals interact with the baby and family when they are affected by care demands.

\section{DISCUSSION}

The theoretical model being mediated by the strength of motivation reveals that the communication of nurses and nursing auxiliaries with the newborn and family transcends the technical scope. During interactions, nursing professionals deliver care with a view to attending them in a more humanized way.

The theoretical evidence of this model permits understanding that the way they establish interactions derives from the nurses and nursing auxiliaries' motivation to communicate with the newborn and family during the hospitalization process, since motivation is the strength that guides them to deliver care focused on the newborn and family.

Human motivation is accountable for the intensity and quality of an individual's effort when working towards his(er) objectives ${ }^{(12-13)}$. In this perspective, the intensity and quality of nursing professionals' effort in the interaction with the newborn and family reflect on the quality of interactions they establish. Thus, they provide appropriate stimuli for the baby's development, prepare themselves to use different strategies of communication with mothers, show affection, and help them to use their personal abilities as a strategy to promote bonding between family and child and, consequently, health recovery. These findings comply with literature, according to which what people communicate is determined by the perception they have of themselves and of others in a certain situation and also perception of aspects of one's motivation ${ }^{(14)}$

Due the interrelation existent between motivation, perception and communication, nursing professionals assume their internal dialog and interpret what they transmit to the baby and family, from the perspective of their motivation, and perceive that their behavior makes them establish bonding with the baby and a friendly relation with the family.

It is also evidenced that nursing professionals, in order to deal with the tension generated by the care demands, react by inhibiting their motivation when communicating with the baby, and interact with the child only to attend his(er) physical needs, and also find difficult to talk to parents, including talking about the child, and even stop greeting them.

Human motivation is cyclical, repetitive and composed of stages that alternate or repeat ${ }^{(15)}$. It occurs due to some temporary and transitory human need and because of a necessity, the organic balance is broken, generating tension, dissatisfaction, discomfort and unbalance. To deal with these aspects, one reacts with behavior that release tension or get rid of the discomfort generated by the need ${ }^{(14)}$.

\section{FINAL CONSIDERATIONS}

The theoretical model presented entails important contributions for nursing care practice because it reveals the importance of professionals motivation strength to establish interactions, which effectively attend the needs of the newborn and family during a hospitalization process. Acquiring this knowledge, nurses can carefully consider their communication with clients, based on their motivation to interact.

The theoretical model also appoints the need of those responsible for the management of health units to re-think the influence of contextual elements found in the study, so as to favor effective communication of nursing professionals with clients and, consequently, qualitative improvement of the delivered care.

It is worth highlighting that, according to Grounded theory, this is not a closed theoretical model. Instead, it can be modified and expanded, based on new data that allow for a better understanding of the communication experience of nursing professionals as well as the family members they interact with during the care process.

\section{REFERENCIAS}

1. Bialoskurki M, Cox $\mathrm{CL}$, Hayes JA. The nature of attachment in the neonatal intensive care unit. J Perinatal Neonatal Nurs.
$1999 ; 13: 66-77$

2. Kenner C. Caring for the NICU parent. J Perinatal Neonatal Nurs. $1990 ; 4: 78-87$.

3. Bakewell-Sachs S, Gennaro S. Parenting the post-NICU 
infant. Am J Matern-Child Nurs 2004; 29(6):398-403.

4. McGrath JM. Building relationships with families in the NICU: exploring the guarded alliance. J Perinatal Neonatal Nurs. 2001; 15(3):74-83.

5. Fenwick J, Barclay L, Schimied V. 'Chatting': an important clinical tool in facilitating mothering in neonatal nurseries. J Adv Nurs 2001; 35(5): 583-93.

6. Griffin, T. Family-centered care in the NICU. J Perinat Neonat Nurs 2006; 20(1):98-102.

7. Blumer $\mathrm{H}$. Symbolic interacionism: perspective and method. California: Prentice Hall; 1969.

8. Hargie ODW, editor. The handbook of communication skills. In: Hargie ODW. Interpersonal communication: a theorical framework. $2^{\text {nd }}$ ed. London: Routledge; 1997. p. 29-63.

9. Glaser BG. Theoretical sensitivity: advances in the methodology of grounded theory.San Francisco: University of California; 1978.
10. Pinheiro EM, Kakehashi TY, Angelo M. O uso de filmagem em pesquisas qualitativas. Rev Lat-am. Enfermagem 2005; 13(5):717-22.

11. Strauss AL, Corbin J. Basics of qualitative research: Grounded theory procedures and techniques. California: Sage; 1991.

12. Robbins SP. Comportamento organizacional. In: Robbins SP. Conceitos básicos de motivação. 9a ed. São Paulo: Afiliada; 2002. p. 151-80.

13. Kofmen F. Management. São Paulo: Antakarana; 2002.

14. Chiavenato I. Administração de recursos humanos: fundamentos básicos. In: Chiavenato I. As pessoas. 4a ed. São Paulo: Atlas; 1999. p. 82-127.

15. Chiavenato I. Gerenciando pessoas: como transformar gerentes em gestores de pessoas. $4^{a}$ ed. São Paulo: Afiliada; 2002. p. 171-98. 